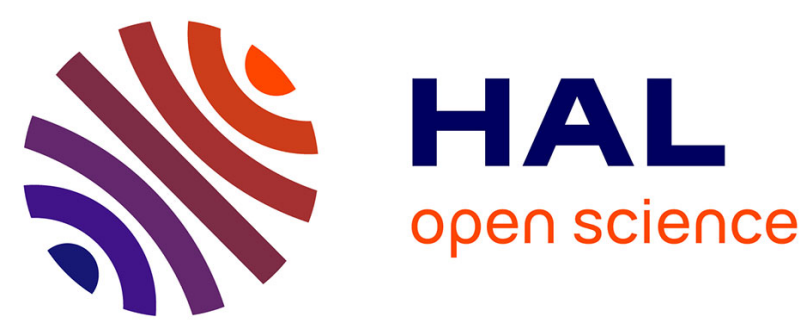

\title{
Performance investigation of reciprocating pump running with organic fluid for organic Rankine cycle
}

Arnaud Landelle, Nicolas Tauveron, Rémi Revellin, Philippe Haberschill, Stephane Colasson, Vincent Roussel

\section{To cite this version:}

Arnaud Landelle, Nicolas Tauveron, Rémi Revellin, Philippe Haberschill, Stephane Colasson, et al.. Performance investigation of reciprocating pump running with organic fluid for organic Rankine cycle. Applied Thermal Engineering, 2017, 113, pp.962 - 969. 10.1016/j.applthermaleng.2016.11.096 . hal01457279

\author{
HAL Id: hal-01457279 \\ https://hal.science/hal-01457279
}

Submitted on 6 Feb 2017

HAL is a multi-disciplinary open access archive for the deposit and dissemination of scientific research documents, whether they are published or not. The documents may come from teaching and research institutions in France or abroad, or from public or private research centers.
L'archive ouverte pluridisciplinaire $\mathbf{H A L}$, est destinée au dépôt et à la diffusion de documents scientifiques de niveau recherche, publiés ou non, émanant des établissements d'enseignement et de recherche français ou étrangers, des laboratoires publics ou privés. 
Research Paper

\title{
Performance investigation of reciprocating pump running with organic fluid for organic Rankine cycle
}

\author{
Arnaud Landelle a,b,c,d,*, Nicolas Tauveron ${ }^{\mathrm{a}, \mathrm{b}}$, Rémi Revellin ${ }^{\mathrm{c}}$, Philippe Haberschill ${ }^{\mathrm{c}}$, Stephane Colasson ${ }^{\mathrm{a}, \mathrm{b}}$, \\ Vincent Roussel ${ }^{\mathrm{a}, \mathrm{b}}$
}

a Université Grenoble Alpes, F-38000 Grenoble, France

${ }^{\mathrm{b}}$ CEA, LITEN, LS2T, 17 rue des Martyrs, F-38054 Grenoble, France

${ }^{\mathrm{C} U n i v}$ Lyon, CNRS, INSA-Lyon, Université Claude Bernard Lyon 1, CETHIL UMR5008, F-69621 Villeurbane, France

d ADEME, 20 av. du Grésillé, F-49004 Angers, France

\section{H I G H L I G H T S}

- Experimental investigation of reciprocating pump with organic fluid.

- Pump power chain analysis and modelling.

- Pump cavitation analysis and impact on ORC performance evaluation.

\section{A R T I C L E I N F O}

\section{Article history:}

Received 1 September 2016

Accepted 13 November 2016

Available online 14 November 2016

\section{Keywords:}

Organic Rankine cycle

Feed pump

Organic fluids

Experimental

Energy efficiency

Cavitation

\begin{abstract}
A B S T R A C T
Organic Rankine cycles (ORC) are used to convert lowgrade heat sources into power. Current research and development investigate small scale and variable heat sources application such as waste heat recovery. Many experimental data on ORC are available. Feed-pump performances achieved are lower than expected and some authors reported cavitation issue. Pump performance has a non-negligible impact over the ORC performance, especially for transcritical cycles. Operations of diaphragm pumps in three different test benches with different fluid and pump size are analyzed. A semi-empirical model of the pump power chain is proposed and validated. Energetic analysis show highlevel of losses in the variable speed drive and electric motor, mainly due to design oversizing. Then a model and analysis of reciprocating pump volumetric efficiency is proposed, taking into account fluid properties. Finally, cavitation limits in different conditions are calculated. Required Net Positive Suction Head (NPSHr) calculated for R134a are found to be in accordance with manufacturer limits for water. Pump vibration sensor could be used for cavitation monitoring. This work gives information for ORC feed-pump simulation, design and operation.
\end{abstract}

๔ 2016 Elsevier Ltd. All rights reserved.

\section{Introduction}

The organic Rankine cycle (ORC) is a heat to power conversion technology suitable for heat sources between $80^{\circ} \mathrm{C}$ and $300^{\circ} \mathrm{C}$ [1]. Current commercial ORC units ranges from $10 \mathrm{kWe}$ to 10 MWe and are used for various applications such as geothermal energy, biomass (usually for combined heat and power), thermal solar plants and waste heat recovery [2]. The Rankine cycle is a thermodynamic cycle using the power gain between liquid compression and vapor expansion. The ratio between pump consump-

\footnotetext{
* Corresponding author at: CEA, LITEN, LS2T, 17 rue des Martyrs, F-38054 Grenoble, France.

E-mail address: arnaud.landelle@cea.fr (A. Landelle).
}

tion and expander output power is called back work ratio (BWR) [3]. In steam Rankine cycle, the BWR is very low and therefore feed-pump performance has a negligible impact over the engine thermal efficiency. In ORC, this assumption is no longer appropriate as BWR is respectively about 2 and 4 times higher for R245fa and R134a compared to water. BWR is increasing as the heat source temperature and fluid critical temperature is low [3,4]. Operating above the critical point strongly increase the BWR (Fig. 1). Therefore, pump efficiency has a strong impact on transcritical ORC thermal efficiency [5]. In numerical study or engine design, pump efficiency is taken between 65 and 85\% [4]. Few ORC experimental studies provides pump real data or analysis. Fig. 2 shows an overview of ORC feed-pump performance reported in the literature. For an ORC of a kW scale, pump mean efficiency is 


\begin{tabular}{|llll|}
\hline \multicolumn{2}{|l|}{ Nomenclature } & & \\
$\mathrm{m}$ & mass flow rate $(\mathrm{kg} / \mathrm{s})$ & el & electric (power) \\
$\mathrm{P}$ & pressure $(\mathrm{bar})$ & esti & estimated (model) \\
$\mathrm{Q}$ & heat transfer $\left(\mathrm{W}_{\text {th }}\right)$ & flu & fluid \\
$\mathrm{T}$ & temperature $\left({ }^{\circ} \mathrm{C}\right)$ & hyd & hydraulic (power) \\
$\mathrm{V}$ & volume flow rate $\left(\mathrm{m}^{3} / \mathrm{h}\right)$ & is & isentropic \\
$\mathrm{V}$ & volume $\left(\mathrm{m}^{3}\right)$ & in & inlet \\
$\mathrm{W}$ & power $(\mathrm{W})$ & leak & leakage \\
$\beta_{\mathrm{T}}$ & isothermal compressibility coef. $\left(\mathrm{Pa}^{-1}\right)$ & los & losses \\
$\Delta$ or $\delta$ & difference & meas & measured \\
$\eta$ & efficiency $(-)$ & me & mechanical (power) \\
$\mu$ & dynamic viscosity $($ Pa s) & mot & motor \\
$\rho$ & density $\left(\mathrm{kg} / \mathrm{m}^{3}\right)$ & $\mathrm{n}$ & nominal \\
$\Phi$ & irreversible dissipation $(\mathrm{W})$ & 0 & reference \\
$\Omega$ & rotational speed $(\mathrm{rpm})$ & out & outlet \\
& & pp & pump \\
Subscript & & sat & saturation \\
comp & compressed & suc & suction \\
dead & dead (volume) & $\mathrm{t}$ & transferred \\
dis & discharge & vol & volumetric \\
disp & displaced & vsd & variable speed drive \\
& & & \\
\hline
\end{tabular}

Superheating $10^{\circ} \mathrm{C}$; $\operatorname{Tmin} 20^{\circ} \mathrm{C}$; Subcooling $10^{\circ} \mathrm{C}$; $\eta$ exp $70 \%$; $\eta$ pump

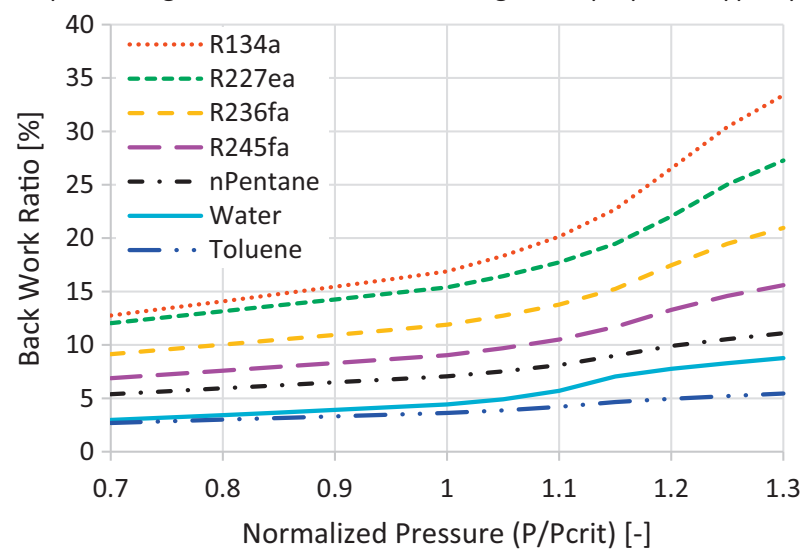

Fig. 1. Back work ratio function of evaporative pressure.

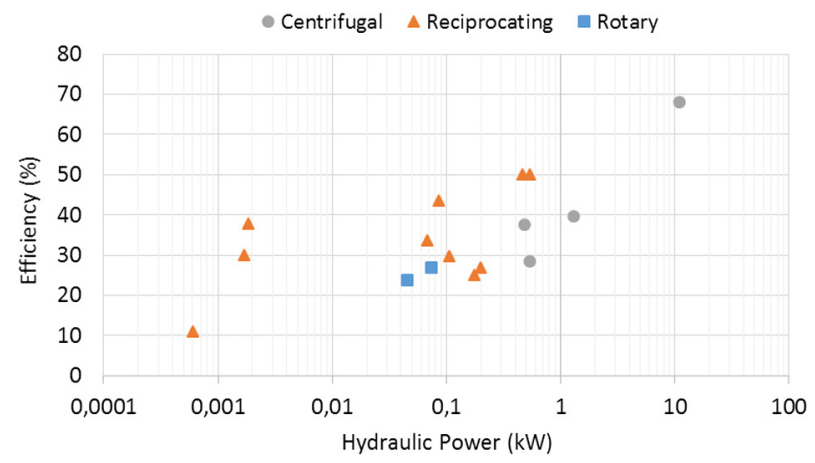

Fig. 2. Reported pump maximum efficiency and hydraulic power.

$35 \%$ and maximum efficiency is about $50 \%$ which is lower than typical design values. Performances are low, especially for small-scale units. Yamada et al. [6] even reported a negative net power (i.e.
BWR above 100\%) for its micro-ORC prototype and proposed a pumpless system as an alternative.

Another issue of pump operation in ORC is the cavitation. Cavitation occurs when fluid at the pump inlet get close to saturation, it leads to flow rate reduction and pump damages. Cavitation is believed to be more serious with organic fluid since compared to water, they have lower latent heat of vaporization and evaporation temperature [7]. Pump manufacturer use the Net Positive Suction Head (NPSH) for cavitation analysis and prevention. NPSH is the difference between the measured pump inlet pressure and the fluid vapor pressure for the pump inlet temperature. In ORC literature, the subcooling is often used instead of the NPSH. The subcooling is the difference between the fluid vapor temperature for the pump inlet pressure and the measured pump inlet temperature. Both express the gap to saturation condition, either in pressure or temperature units. Yang et al. [7] reported cavitation in piston pump for subcooling under $20^{\circ} \mathrm{C}$. Dumont et al. [8] and Chang et al. [9] plunger pumps requested respectively $10^{\circ} \mathrm{C}$ and $11^{\circ} \mathrm{C}$ subcooling to avoid cavitation. Leontaritis et al. [10] diaphragm pump required 0.5 bar of NPSH whether a $2{ }^{\circ} \mathrm{C}$ subcooling for smooth operation. Decrease the minimum subcooling is essential for ORC, especially at low temperature. Fig. 3 shows evolution of BWR and ORC thermal efficiency function of the subcooling at

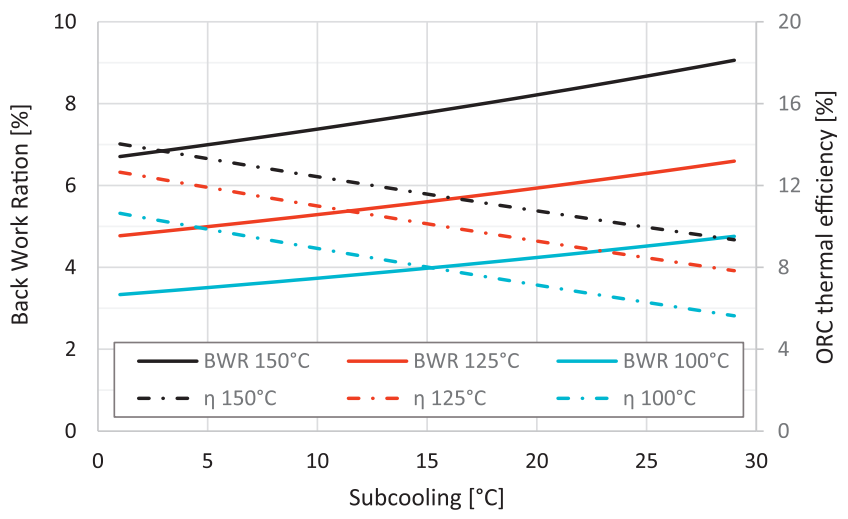

Fig. 3. ORC performance function of subcooling. 
different expander inlet temperature. Quoilin et al. [3] exposes technical solutions to avoid cavitation: addition of a pre-feed pump as Miao et al. [11] did, addition of a liquid subcooler as Dumont et al. [8], Galindo et al. [12] and Leontaritis et al. [10] did.

This study focuses on reciprocating pump type, which is the main type of pump used in the ORC experimental literature $(2 / 3$ of the references), especially in mini-ORC applications (3-50 kW). Objective of the present study is to identify energy losses in the pump power chain and ways of improvement, investigate cavitation limits and make a comparison with pump manufacturer data, usually performed with water.

\section{Experimental facilities and procedures}

\subsection{Experimental setups}

An experimental investigation is carried out on diaphragm pumps. Three test benches, working with different pump models and fluids, are used to develop this analysis and validate models. Table 1 summarizes each test bench characteristic and pump power chain components with their nominal features. All the pumps are diaphragm triplex single-acting pumps, from Wanner Hydra-Cell. They are driven by induction motors coupled to variable frequency drive (VSD) for flow control. Pump electrical consumption is measured with power meters, pressure and temperatures are measured at the pump inlet and outlet. Mass flow rate, when available, is measured by Coriolis flowmeter. The shaft rotational speed is either measured by an optical tachometer or from the VSD electrical frequency control. Extensive investigation is performed on the bench called Surcouf [13]. Fig. 4 shows Surcouf bench diagram and installation. Details about the CPV/ Rankine and Solammor bench can be found respectively in $[14,15]$.

\subsection{Test description}

Different tests are performed to characterize the pumping system. Motor standalone test, with the pump shaft disconnected from motor shaft to characterize the VSD and motor static losses - only performed in the Surcouf bench. Pumping test, at different shaft speeds and pump pressure differences to cover different pump loads, subcooling is kept high enough to avoid cavitation. Those tests provide data for the power chain analysis and the pump volumetric efficiency analysis. In cavitation test, shaft speed and pressure difference are kept constant, subcooling is reduced until flowrate drops significantly. Table 2 shows the range of operating conditions for each bench. The hydraulic power is the mechanical power transferred by the pump to the fluid (i.e. useful power) $\mathrm{W}_{\mathrm{hy}}=\mathrm{m}_{\mathrm{flu}} \cdot \int(1 / \rho) \cdot \mathrm{dP}$. Assuming fluid incompressibility, $\mathrm{W}_{\text {hy }}=\mathrm{V} \cdot \Delta \mathrm{P}$. Fluid thermophysic properties are computed with the Coolprop library [16].

Table 1

Test benches description.

\begin{tabular}{rlll}
\hline & Surcouf & CPV/Rankine & Solammor \\
\hline Pump & Hydra-Cell G03X & Hydra-Cell G10X & Hydra-Cell G03X \\
& $11.3 \mathrm{l} / \mathrm{m}-70 \mathrm{bar}$ & $29 \mathrm{l} / \mathrm{m}-70 \mathrm{bar}$ & $11.3 \mathrm{l} / \mathrm{m}-70 \mathrm{bar}$ \\
Motor & Leroy-Somer LS90L & Valiadis K132S & Leroy-Somer LS71 M \\
& $1.8 \mathrm{~kW} \eta: 80 \%$ & $3 \mathrm{~kW} \eta: 86 \%$ & $0.25 \mathrm{~kW} \eta: 69 \%$ \\
& $1438 \mathrm{rpm}$ & $960 \mathrm{rpm}$ & $1425 \mathrm{rpm}$ \\
VSD & Leroy-Somer & Siemens SED24/ & Leroy-Somer \\
& Varmeca 32 & $32 \mathrm{~B}$ & Varmeca 32 \\
Speed & $1: 1$ & $1: 1$ & $5: 1$ \\
red. & & & $\mathrm{NH}_{3} / \mathrm{H}_{2} \mathrm{O}$ \\
Fluid & R134a & R404a &
\end{tabular}

\section{Pump performance: results and discussion}

\subsection{Energy efficiency}

An energetic diagram of the system is proposed in Fig. 5 to identify losses in the pump power chain. $W_{\mathrm{el}}$ is the measured electrical consumption, $W_{\text {me }}$ is the mechanical shaft power, $Q_{\text {los }}$ are heat powers lost to the ambient environment by different components. Pumping is assumed to be fast enough to neglect heat transfer between the pump and the fluid. Therefore, the power transferred by the pump to the fluid $\mathrm{W}_{\mathrm{t}}$ is composed of the hydraulic power $W_{\text {hy }}$ and the irreversible dissipation $\Phi$. Different efficiencies are defined from those powers: the global efficiency of the pumping system $\eta_{\text {global }}=W_{\text {hy }} / W_{\text {el }}$, the pump efficiency $\eta_{\text {pump }}=W_{\text {hy }} / W_{\text {me }}$ and the isentropic efficiency of the pump $\eta_{\text {is }}=W_{\text {hy }} / W_{t}$. For each component of the power chain, a semi-empirical model is proposed based on literature review, manufacturer data and experiments. Unknown parameters are estimated by minimizing the error-objective function between estimated and measured electric consumption: $\mathrm{F}=\sum\left(\left(\mathrm{W}_{\mathrm{el}, \text { meas }}-\mathrm{W}_{\mathrm{el}, \text { esti }}\right) / \mathrm{W}_{\mathrm{el}, \text { esti }}\right)^{2}$.

- Variable speed drive: According to the IEC 60034-31 standard [17], VSD have statics losses, plus losses proportional to the output power and output frequency. Deprez [18] investigated efficiency of a $11 \mathrm{~kW}$ motor and VSD combination. As a first approximation, VSD power losses are considered constant. Under this assumption, $\mathrm{Q}_{\mathrm{los}, \mathrm{VSD}}=\mathrm{K}_{1} . \mathrm{K}_{1}$ is a constant model parameter to estimate from experimentation.

- Electric motor: Induction motors have been deeply investigated under variable speed and load. The IEC 60034-31 standard [17] provide a part load efficiency correlation based on motor manufacturer data. In this correlation, motor losses are a linear function of $W_{\text {me. }}^{2}$ Li et al. [19] proposed a new correlation for motor efficiency drive by a VSD, under variable speed and load. VSD control is assumed to be a constant $\mathrm{U} / \mathrm{f}$ command type, meaning voltage is proportional to the frequency at the VSD output. The motor losses correlation uses motor nominal performance provided by the manufacturer.

$\mathrm{Q}_{\text {los,mot }}=\mathrm{W}_{\mathrm{mot}, \mathrm{n}} \cdot\left(1 / \eta_{\mathrm{mot}, \mathrm{n}}-1\right) \cdot\left[\alpha \cdot \mathrm{W}_{\mathrm{me}}^{2} / \mathrm{W}_{\mathrm{mot}, \mathrm{n}}^{2}+(1-\alpha)\right.$.
$\left.\Omega_{\mathrm{mot}}^{2} / \Omega_{\mathrm{mot}, \mathrm{n}}^{2}\right]$.

Li set the $\alpha$ model parameter to 0.7 , but it can be estimated from experimentation (limit values: $[0 ; 1]$ ).

- Pump: The pump manufacturer proposed a correlation to estimate the required power based on pump shaft speed and hydraulic power: $W_{\text {me }}=K_{2} \cdot \Omega_{p p}+K_{3} \cdot W_{\text {hy }} \cdot K_{2}$ and $K_{3}$ parameters are given by the pump manufacturer, but they can be estimated from experimentation. In the Surcouf bench, relative deviation between manufacturer and experimental parameter values are $1.7 \%$ for $K_{2}$ and $3.2 \%$ for $K_{3}$. Therefore, manufacturer parameters estimated for water are applicable to other fluids. This correlation doesn't discriminate losses to the environment $Q_{\text {los,pp }}$ and internal fluid dissipation $\Phi$. The transferred power $\mathrm{W}_{\mathrm{t}}=\mathrm{m}_{\mathrm{flu}} \cdot\left(\mathrm{h}_{\mathrm{dis}}-\mathrm{h}_{\text {sup }}\right)$ is computed with pressure and temperature measurements for enthalpy estimation and leads to an estimation of $\Phi$ by subtracting the hydraulic power $W_{\text {hy }}$. However, it is highly sensitive to the temperature measurement. A $0.5^{\circ} \mathrm{C}$ uncertainty on both temperatures results in a pump isentropic efficiency uncertainty up to $30 \%$. By definition, isentropic efficiency is higher than pump efficiency. So as a first approximation, the isentropic efficiency is estimated to equal the pump maximum efficiency $\eta_{\text {pump,max }}=1 / K_{3}$.

Table 3 resumes power chain semi-empirical model equations and parameters, note that pump and motor shaft speeds can differ 

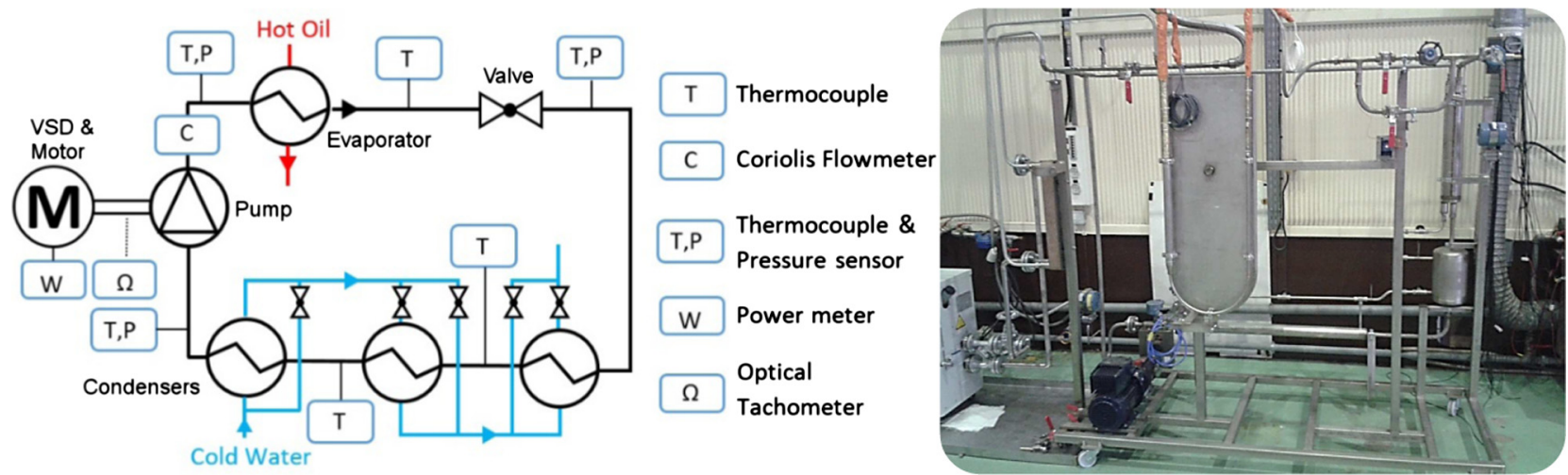

Fig. 4. Surcouf test bench.

Table 2

Range of operating conditions.

\begin{tabular}{|c|c|c|c|c|}
\hline & Surcouf & CPV/Rankine & Solammor & Max uncertainty \\
\hline Pressure differential $\Delta \mathrm{P}$ [bar] & $0-36$ & $5.8-24.9$ & $4.4-8.9$ & \pm 0.5 bar \\
\hline Subcooling $\left[{ }^{\circ} \mathrm{C}\right]$ & $0.2-44$ & $0-2.3$ & $\mathrm{n} / \mathrm{a}$ & $\pm 0.5^{\circ} \mathrm{C}$ \\
\hline Pump shaft speed [rpm] & $0-1505$ & $384-864$ & $130-408$ & $\pm 1 \mathrm{rpm}$ \\
\hline Mass flow rate $(\mathrm{g} / \mathrm{s})$ & $42-201$ & $100-326$ & $12-38$ & $\pm 0.5 \mathrm{~g} / \mathrm{s}$ \\
\hline Hydraulic power (W) & $0-561$ & $55-760$ & $9-32$ & $\pm 10 \mathrm{~W}$ \\
\hline Electrical power (W) & $250-1080$ & 1000-1985 & $97-189$ & $\pm 20 \mathrm{~W}$ \\
\hline
\end{tabular}

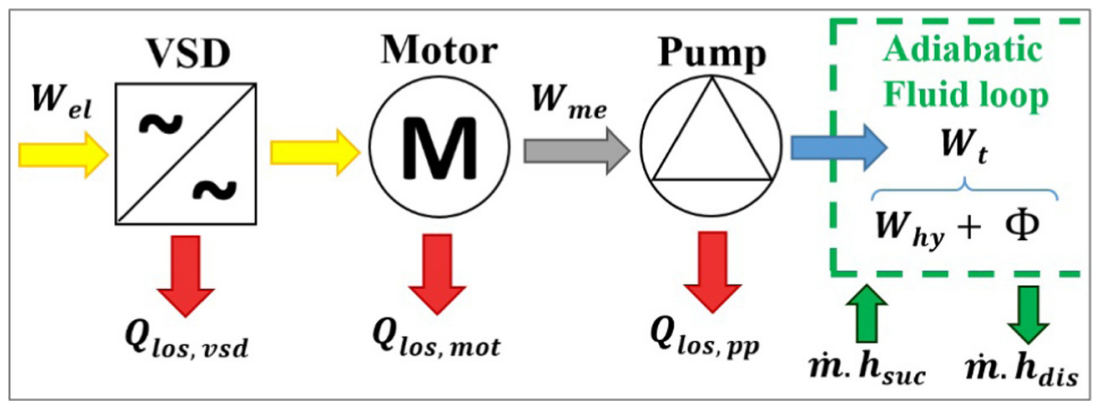

Fig. 5. Pump power chain diagram.

Table 3

Power chain model: equations, parameters and deviation.

\begin{tabular}{|c|c|c|c|c|c|c|}
\hline & & & & Surcouf & CPV/Rankine & Solammor \\
\hline \multicolumn{7}{|c|}{ Pump power: $\mathrm{W}_{\mathrm{me}}=\mathrm{K}_{2} \cdot \Omega_{\mathrm{pp}}+\mathrm{K}_{3} \cdot \mathrm{V} \cdot \Delta \mathrm{P}$} \\
\hline$\Omega_{\mathrm{pp}}$ & $\mathrm{rpm}$ & Pump shaft speed & Input & & & \\
\hline$\Delta \mathrm{P}$ & $\mathrm{Pa}$ & Pressure differential & Input & & & \\
\hline V & $\mathrm{m}^{3} / \mathrm{s}$ & Volumetric flow & Input & & & \\
\hline $\mathrm{K}_{2}$ & $\mathrm{~W} / \mathrm{rpm}$ & Friction coefficient & Manufacturer or empirical & 0.0711 & 0.1777 & 0.0711 \\
\hline $\mathrm{K}_{3}$ & - & Efficiency coefficient & Manufacturer or empirical & 1.174 & 1.174 & 1.174 \\
\hline \multicolumn{7}{|c|}{ VSD \& motor power: $\mathrm{W}_{\mathrm{el}}-\mathrm{K}_{1}-\mathrm{W}_{\mathrm{mot}, \mathrm{n}} \cdot\left(1 / \eta_{\mathrm{mot}, \mathrm{n}}-1\right) \cdot\left[\alpha \cdot \mathrm{W}_{\mathrm{me}}^{2} / \mathrm{W}_{\mathrm{mot}, \mathrm{n}}^{2}+(1-\alpha) \cdot \Omega_{\mathrm{mot}}^{2} / \Omega_{\mathrm{mot}, \mathrm{n}}^{2}\right]$} \\
\hline $\mathrm{W}_{\mathrm{me}}$ & $\mathrm{W}$ & Shaft power & Input & & & \\
\hline$\Omega_{\mathrm{mot}}$ & rpm & Motor shaft speed & Input & & & \\
\hline $\mathrm{W}_{\text {mot,n }}$ & W & Motor nominal power & Manufacturer & 1800 & 3000 & 250 \\
\hline$\Omega_{\mathrm{mot}, \mathrm{n}}$ & rpm & Motor nominal speed & Manufacturer & 1438 & 960 & 1425 \\
\hline$\eta_{\text {mot,n }}$ & - & Motor nominal efficiency & Manufacturer & 0.794 & 0.864 & 0.694 \\
\hline $\mathrm{K}_{1}$ & W & VSD losses coefficiency & Empirical & $219^{\mathrm{a}}$ & $904^{\mathrm{a}}$ & $67.7^{\mathrm{a}}$ \\
\hline$\alpha$ & - & Motor losses repartition & Empirical or default (0.7) & $0.563^{\mathrm{a}}$ & 0.7 & $0.59^{\mathrm{a}}$ \\
\hline \multicolumn{4}{|c|}{ Electric power standard deviation between model and experiment } & $20.3 \mathrm{~W}$ & $51.9 \mathrm{~W}$ & $11.2 \mathrm{~W}$ \\
\hline
\end{tabular}

${ }^{a}$ Value established from experiment. 


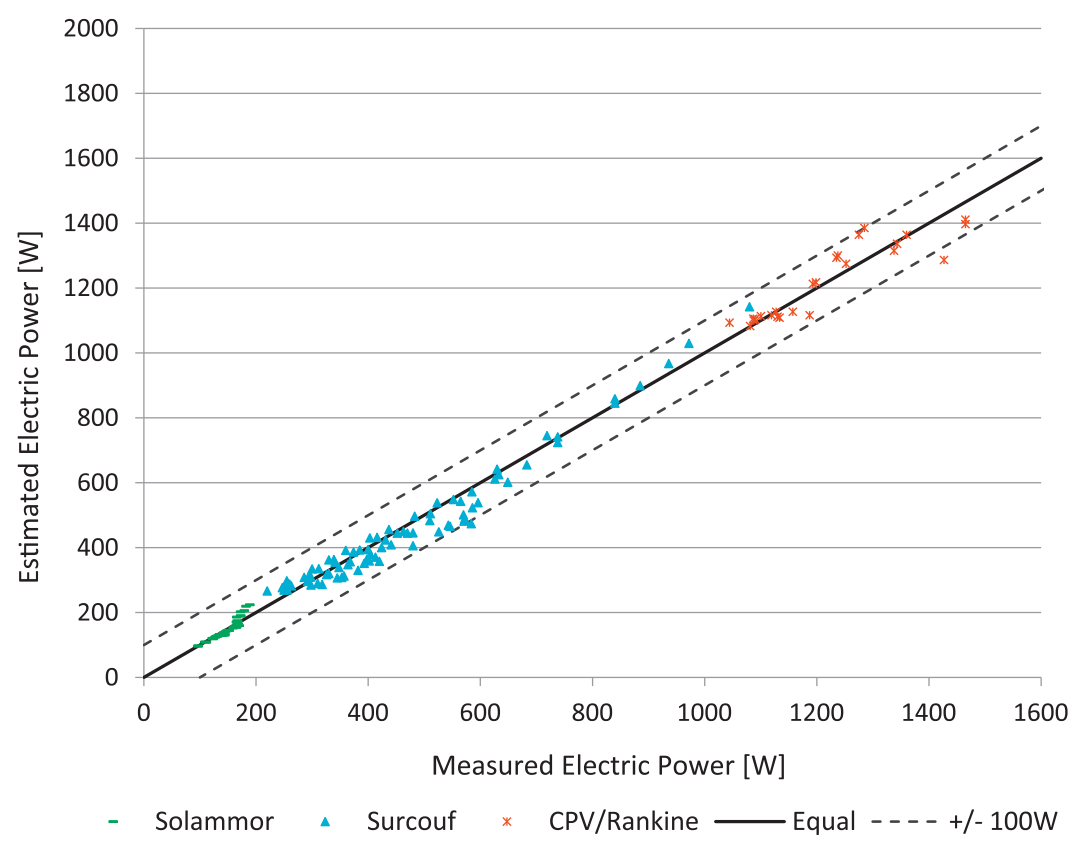

Fig. 6. Estimated vs. measured pump electric consumption.

if a mechanical speed reduction is implemented. Pump, motor \& VSD models are combined and unknown parameters are estimated from experimental data. Standard deviation between measurement and model outputs are presented in Table 3 for each test bench. Comparison between model estimation and measurement is shown in Fig. 6.

Model analysis gives an overview of losses location in the power chain. Surcouf model is run for different shaft speed and pressure difference and some scenario are shown in Fig. 7. Pump manufacturer power correlation is found to be in accordance with experiments. According to this correlation, the pump efficiency is only function of the pressure differential since the volumetric flow is assumed to be proportional to the pump shaft speed

$\left(\mathrm{V}=\mathrm{a} \cdot \Omega_{\mathrm{pp}}\right) \cdot \eta_{\mathrm{pump}}=\mathrm{W}_{\mathrm{hy}} / \mathrm{W}_{\mathrm{me}}=\mathrm{V} \cdot \Delta \mathrm{P} /\left(\mathrm{K}_{2} \cdot \Omega_{\mathrm{pp}}+\mathrm{K}_{3} \cdot \mathrm{V} \cdot \Delta \mathrm{P}\right)=\Delta \mathrm{P} /$ $\left(\mathrm{K}_{2} / \mathrm{a}+\mathrm{K}_{3} \cdot \Delta \mathrm{P}\right)$.

Therefore, reciprocating pumps becomes more efficient at high pressure difference. VSD losses represents about $1 / 3$ of the consumption and should be deeply investigated. Its benefits should be compared with other flow variation methods such as gearbox or fluid bypass. In experiments, motor loads is always under $25 \%$ leading to very low efficiency, especially as the motor rated power is low [17]. Even if benches were running at their design point, motor load would be around 50\%. Design matching between components and cycle should be carefully checked in commercial units. Accumulation of margins at each stage during the ORC design and component selection can lead to a harmful oversizing.

\subsection{Volumetric efficiency}

In reciprocating pump, the volume flow without pressure $V_{0}$ is proportional to the pump shaft speed and the piston displaced volume $v_{\text {disp }} . V_{0}$ is used as the reference flow to compute the volumetric efficiency $\eta_{\mathrm{vol}}=\mathrm{V} / \mathrm{V}_{0}$. The volumetric flow can be either estimated at the pump inlet or outlet leading to the confusion in efficiency definition. In this study, the discharge flow is used. Different factors are affecting the volumetric efficiency [20] such as valves leakages, fluid compressibility and NPSH. Subcooling is kept high to restrict cavitation effect over the volumetric efficiency.

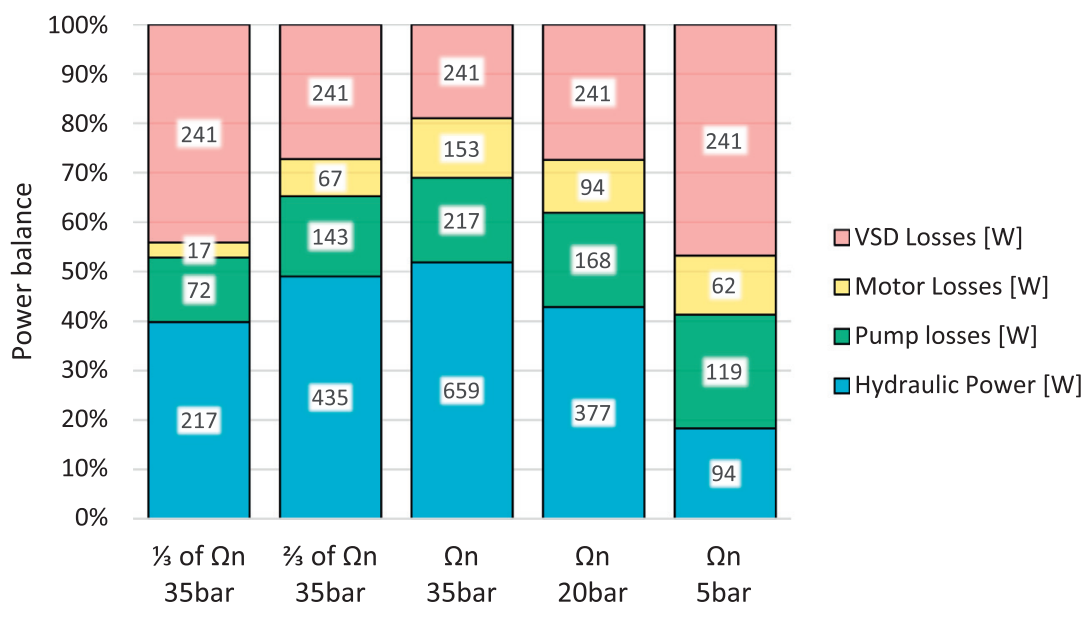

Fig. 7. Surcouf pump power balance simulation for different shaft speed and pressure scenario. 

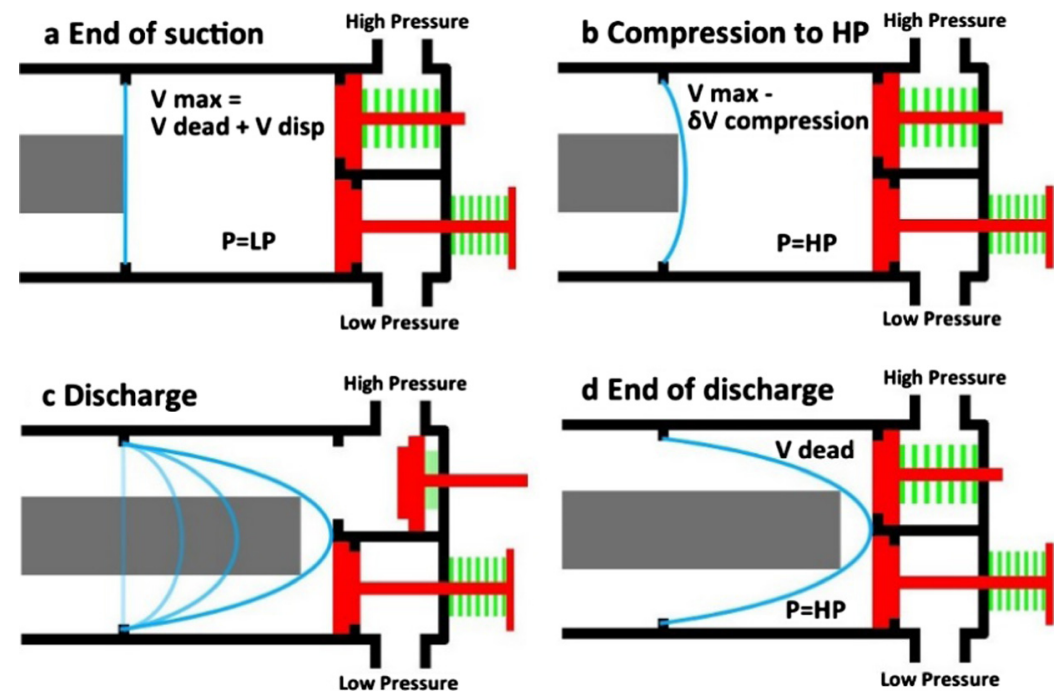

Fig. 8. Reciprocating pump discharge process.

Johnston [21] explained that valve leakage is mainly due to delays in valve closing. This delay is assumed inversely proportional to the shaft speed and number of openings is proportional to the shaft speed. So, valve leakage flowrate is independent of the speed and is modeled by a continuous leakage flowrate using the equation proposed by De Chargeres and Rey [22] $\mathrm{V}_{\text {leak }}=\mathrm{A} \cdot \Delta \mathrm{P} / \mu$ with $\mathrm{A}$ an empirical geometric coefficient. Fig. 8 presents the pump process. The isothermal compressibility coefficient $\beta_{\mathrm{T}}$ is introduced to define the output volume per stroke

$\mathrm{v}_{\text {out }}=\left(\mathrm{v}_{\max }-\delta \mathrm{v}_{\text {comp }}\right)-\mathrm{v}_{\text {dead }}=\mathrm{v}_{\text {disp }}-\Delta \mathrm{P} \cdot \beta_{\mathrm{T}} \cdot\left(\mathrm{v}_{\text {disp }}+\mathrm{v}_{\text {dead }}\right)$.

Combining leakage and compressibility equations, the volumetric efficiency is:

$\eta_{\mathrm{vol}}=1-\Delta \mathrm{P} \cdot \beta_{\mathrm{T} .}\left(1+\mathrm{v}_{\mathrm{dead}} / \mathrm{v}_{\mathrm{disp}}\right)-\mathrm{A} \cdot \Delta \mathrm{P} /\left(\mu \cdot \mathrm{v}_{\mathrm{disp}} \cdot \Omega\right)$.

Volumetric efficiency is investigated under various shaft speeds and pressure differential as shown in Fig. 9. Influence of the pressure difference on the volumetric efficiency is linear as expected, but influence of the shaft speed is not clear. Experimental volumetric efficiency is lower than manufacturer correlation. However water, which is usually used for manufacturer correlation, has a compressibility coefficient ten times lower compare to the organic fluid at the pump inlet conditions.

\subsection{Cavitation}

For volumetric pumps, cavitation results in a drop of volumetric flow and an increase in pump vibrations. Consequently, cavitation undermines pump performance and lifetime. An experimental investigation is performed on the Surcouf bench to determine cavitation limits, corresponding to a volumetric flow drop of $3 \%$ compared to noncaviting conditions [20]. Two parameters are used to assess the cavitation in a closed fluid circuit, both describe the margin to the fluid saturation at the pump inlet conditions. The Net Positive Suction Head (NPSH) in pressure unit: $\mathrm{NPSH}=\mathrm{P}_{\mathrm{in}, \mathrm{pp}}-\mathrm{P}_{\mathrm{sat}}\left(\mathrm{T}_{\mathrm{in}, \mathrm{pp}}\right)$, commonly used by pump manufacturers, who provides the minimum NPSH for pump operation. And the subcooling in temperature unit: $T_{\text {subcool }}=T_{\text {sat }}\left(P_{\text {in,pp }}\right)-T_{\text {in,pp }}$, commonly used for cycle thermodynamic analysis. Fig. 10 shows evolution of R134a volumetric flow function of subcooling and NPSH at the pump nominal speed. Cavitation limit at the nominal speed is 0.24 bar for NPSH or $4.4{ }^{\circ} \mathrm{C}$ of subcooling. As depicted in

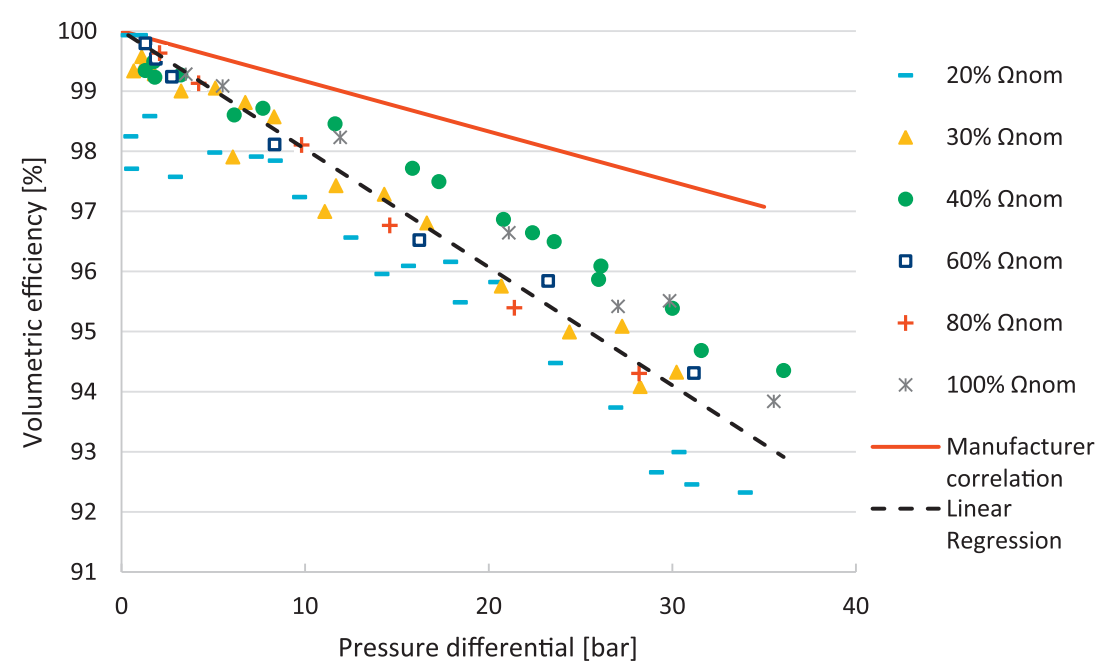

Fig. 9. Pump volumetric efficiency function of pressure differential. 


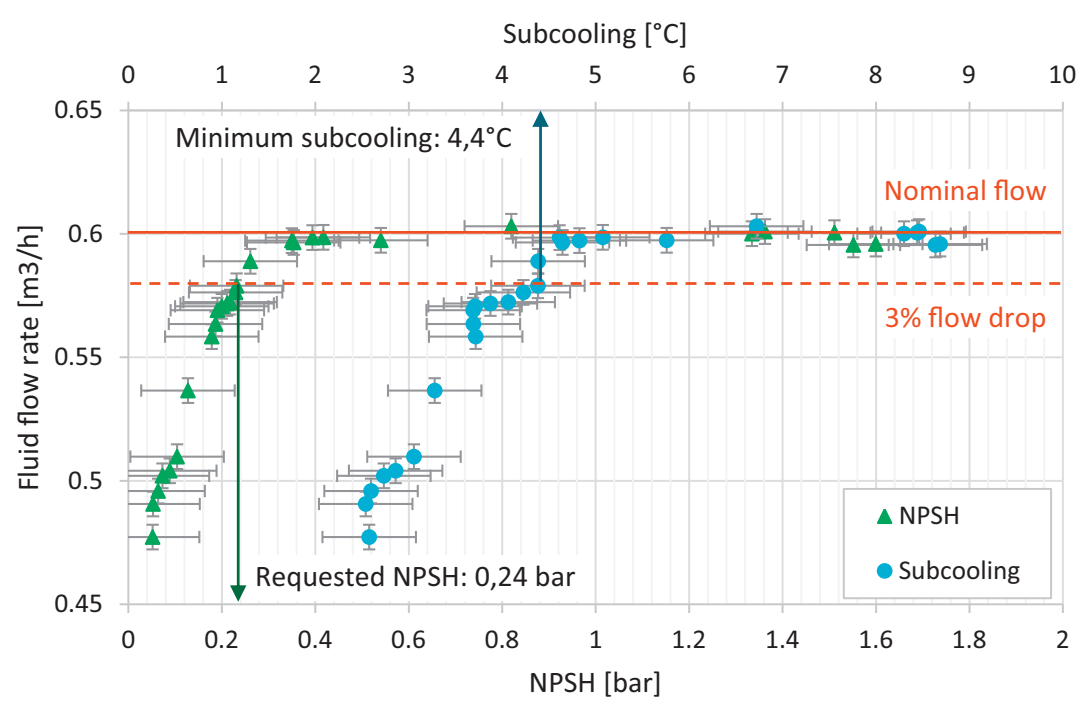

Fig. 10. R134a volumetric flow function of subcooling and NPSHr.

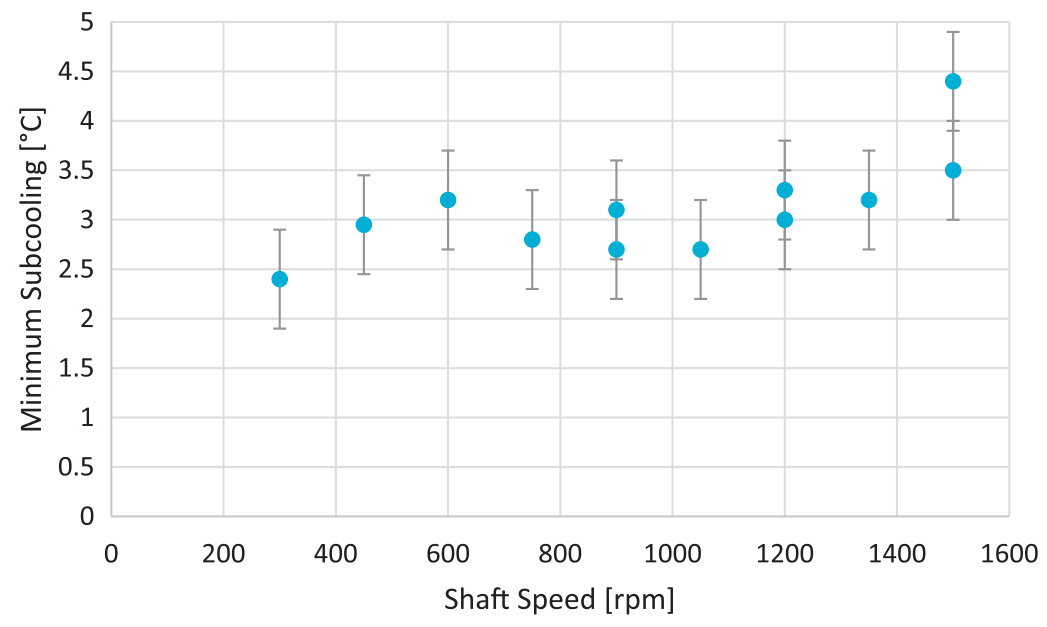

Fig. 11. Evolution of the minimum subcooling with pump shaft speed.

Fig. 11, the minimum subcooling is increasing with the pump shaft speed, ranging from $2.5^{\circ} \mathrm{C}$ to $4.4^{\circ} \mathrm{C}$ for a shaft speed between 20 and $100 \%$ of the nominal speed. Influence of the pump pressure differential on the minimum subcooling has been studied at $70 \%$ of the nominal speed for pressure difference between 5 and 35 bar but no relation can be highlighted, i.e. the minimum subcooling seems independent of the pressure difference.

\section{Conclusions}

In this research paper, performances of reciprocating pump for organic Rankine cycle are investigated through different experimental test benches. Three aspects of the pumping system are investigated: energetic performance, volumetric efficiency and cavitation limits. In addition, semi-empirical models are proposed and validated with experimental data for energetic and volumetric efficiencies. Impact of feed-pump performance on the organic Rankine cycle performances are also discussed. The following conclusions are drawn:

- Pump power chain analysis shown pump performance in agreement with manufacturer data, but underestimated losses in the electrical driving part. Use of variable speed drive results in high losses of nearly $20 \%$ of the initial power consumption in nominal conditions, to $50 \%$ when operating at part load or speed. Driving part is usually designed for pump limit conditions which are usually lower than ORC system limit conditions. Therefore, driving part oversizing results in efficiency drops, especially if the system is running under its nominal load.

- Reciprocating pumps have excellent volumetric efficiency even at high load. Organic fluid have an isothermal compressibility coefficient usually lower compared to water. It results in a lower, but very good, volumetric efficiency compared to water manufacturer data.

- Pump should operate above its cavitation limit. However, increasing cavitation margin reduces ORC thermal efficiency, which is especially harmful as the heat source temperature and therefore maximum efficiency is already low. Experimental cavitation limits are found to be in agreement with manufacturer water data. Cavitation margins could be monitor through accelerometer after a proper calibration.

\section{Acknowledgements}

This work was supported by the French Environment and Energy Management Agency (ADEME) and the French Alternative Energies and Atomic Energy Commission (CEA). 


\section{References}

[1] N. Tauveron, S. Colasson, J.-A. Gruss, Available systems for the conversion of waste heat to electricity, in: Proc. ASME 2014 Int. Mech. Eng. Congr. Expo., 2014, http://dx.doi.org/10.1115/IMECE2014-37984.

[2] P. Colonna, E. Casati, C. Trapp, T. Mathijssen, J. Larjola, T. Turunen-Saaresti, A Uusitalo, Organic Rankine cycle power systems: from the concept to current technology, applications, and an outlook to the future, J. Eng. Gas Turbines Power 137 (2015) 100801-100819, http://dx.doi.org/10.1115/1.4029884.

[3] S. Quoilin, M.V.D. Broek, S. Declaye, P. Dewallef, V. Lemort, Techno-economic survey of organic Rankine cycle (ORC) systems, Renew. Sustain. Energy Rev. 22 (2013) 168-186, http://dx.doi.org/10.1016/j.rser.2013.01.028.

[4] A. Borsukiewicz-Gozdur, Pumping work in the organic Rankine cycle, Appl. Therm. Eng. 51 (2013) 781-786, http://dx.doi.org/10.1016/j. applthermaleng.2012.10.033.

[5] D. Maraver, J. Royo, V. Lemort, S. Quoilin, Systematic optimization of subcritica and transcritical organic Rankine cycles (ORCs) constrained by technical parameters in multiple applications, Appl. Energy 117 (2014) 11-29, http://dx doi.org/10.1016/j.apenergy.2013.11.076.

[6] N. Yamada, M. Watanabe, A. Hoshi, Experiment on pumpless Rankine-type cycle with scroll expander, Energy 49 (2013) 137-145, http://dx.doi.org 10.1016/j.energy.2012.10.027.

[7] X. Yang, J. Xu, Z. Miao, J. Zou, C. Yu, Operation of an organic Rankine cycle dependent on pumping flow rates and expander torques, Energy (2015), http://dx.doi.org/10.1016/j.energy.2015.07.121.

[8] O. Dumont, S. Quoilin, V. Lemort, Experimental investigation of a reversible heat pump/organic Rankine cycle unit designed to be coupled with a passive house to get a Net Zero Energy Building, Int. J. Refrig. 54 (2015) 190-203, http://dx.doi.org/10.1016/j.ijrefrig.2015.03.008.

[9] J.-C. Chang, T.-C. Hung, Y.-L. He, W. Zhang, Experimental study on lowtemperature organic Rankine cycle utilizing scroll type expander, Appl. Energy 155 (2015) 150-159, http://dx.doi.org/10.1016/j.apenergy.2015.05.118.

[10] A.-D. Leontaritis, P. Pallis, S. Karellas, A. Papastergiou, N. Antoniou, P. Vourliotis, N.M. Kakalis, G. Dimopoulos, Experimental study on a low temperature ORC unit for onboard waste heat recovery from marine diesel engines, in: 3rd Int. Semin. ORC Power Syst., Brussels, 2015.
[11] Z. Miao, J. Xu, X. Yang, J. Zou, Operation and performance of a low temperature organic Rankine cycle, Appl. Therm. Eng. 75 (2015) 1065-1075, http://dx.doi. org/10.1016/j.applthermaleng.2014.10.065.

[12] J. Galindo, S. Ruiz, V. Dolz, L. Royo-Pascual, R. Haller, B. Nicolas, Y. Glavatskaya, Experimental and thermodynamic analysis of a bottoming Organic Rankine Cycle (ORC) of gasoline engine using swash-plate expander, Energy Convers. Manage. 103 (2015) 519-532, http://dx.doi.org/10.1016/j.enconman.2015. 06.085 .

[13] A. Landelle, N. Tauveron, P. Haberschill, R. Revellin, S. Colasson, Study of reciprocating pump for supercritical ORC at full and part load operation, in: 3rd Int. Semin. ORC Power Syst., Brussels, 2015.

[14] G. Kosmadakis, D. Manolakos, G. Papadakis, Experimental investigation of a low-temperature organic Rankine cycle (ORC) engine under variable heat input operating at both subcritical and supercritical conditions, Appl. Therm. Eng. 92 (2016) 1-7, http://dx.doi.org/10.1016/j.applthermaleng.2015.09.082.

[15] F. Boudéhenn, H. Demasles, J. Wyttenbach, X. Jobard, D. Chèze, P. Papillon, Development of a $5 \mathrm{~kW}$ cooling capacity ammonia-water absorption chiller for solar cooling applications, Energy Pro. 30 (2012) 35-43, http://dx.doi.org/ 10.1016/j.egypro.2012.11.006.

[16] I.H. Bell, J. Wronski, S. Quoilin, V. Lemort, Pure and pseudo-pure fluid thermophysical property evaluation and the open-source thermophysical property library CoolProp, Ind. Eng. Chem. Res. 53 (2014) 2498-2508, http:// dx.doi.org/10.1021/ie4033999.

[17] IEC, IEC 60034-31: Guide for the selection and application of energy efficient motors including variable-speed applications, 2010

[18] W. Deprez, J. Lemmens, D. Vanhooydonck, W. Symens, K. Stockman, S. Dereyne, J. Driesen, Iso Efficiency Contours as a Concept to Characterize Variable Speed Drive Efficiency, IEEE, Rome, 2010.

[19] Y. Li, M. Liu, J. Lau, B. Zhang, A novel method to determine the motor efficiency under variable speed operations and partial load conditions, Appl. Energy 144 (2015) 234-240, http://dx.doi.org/10.1016/j.apenergy.2015.01.064.

[20] J.E. Miller, The Reciprocating Pump Theory, Design, And Use, second ed., Krieger Publishing Co., 1995.

[21] D.N. Johnston, Numerical modelling of reciprocating pumps with self-acting valves, Proc. Inst. Mech. Eng. Part J. Syst. Control Eng. 205 (1991) 87-96.

[22] B. De Chargeres, R. Rey, Pompes Volumétriques Pour Liquides, Tech. Ing., 2009. 